\title{
APLIKASI RPG BERBASISKAN TEKNOLOGI ANDENGINE PADA PERANGKAT MOBILE ANDROID GINGERBREAD
}

\author{
Budi Yulianto; Andy Budy Pratama; Hutomo Widjaja \\ Computer Science Department, School of Computer Science, Binus University \\ Jln. K. H. Syahdan No. 9 Palmerah Jakarta Barat 11480 \\ laboratory@binus.ac.id
}

\begin{abstract}
This article presents an application development of a Tactical Role-Playing Game based on AndEngine on an Android Gingerbread mobile device. The goals of the research are designing an entertaining application that implements artificial intelligence and AndEngine technology as well as presenting Indonesian cultures. The output of the research is a 2-dimension-based Tactical Role-Playing Game application implemented on Android Gingerbread mobile device and a game engine for creating items and skills of the characters for the game. On the application development phase, the research uses literature study, user requirement analysis, and similar game analysis. The research showed that the game application is developed using 2-dimension perception implementing artificial intelligence and AndEngine technology for having interesting control and appearance for users. In addition, it motivates other programmers for developing other game that presents Indonesian cultures, and uses conditional framerate for reducing battery usage on mobile device.
\end{abstract}

Keywords: game, tactical role-playing, AndEngine, mobile device, Android Gingerbread, conditional framerate

\begin{abstract}
ABSTRAK
Artikel ini menjelaskan pengembangan aplikasi Tactical Role-Playing Game berbasiskan teknologi AndEngine pada perangkat mobile bersistem operasi Android Gingerbread. Penelitian ini bertujuan untuk merancang suatu aplikasi hiburan yang mengimplementasikan kecerdasan buatan dan teknologi AndEngine serta memperkenalkan elemen-elemen kebudayaan Indonesia. Pada perancangannya, penelitian ini menerapkan studi literatur, analisis kebutuhan pengguna, dan analisis game sejenis. Hasil dari penelitian ini berupa aplikasi game dua dimensi bergenre Tactical Role-Playing Game yang diimplementasikan pada perangkat mobile bersistem-operasi Android Gingerbread serta game engine untuk pembuatan item dan skill karakter yang dapat diterapkan pada game. Aplikasi game yang dirancang dengan persepsi dua dimensi ini menerapkan kecerdasan buatan dan teknologi AndEngine sehingga memiliki kontrol dan tampilan yang menarik bagi pengguna; memacu pengembang aplikasi game lainnya untuk mengembangkan aplikasi game sejenis yang menyuguhkan elemenelemen kebudayaan Indonesia; serta memadukan metode conditional framerate untuk penghematan baterai pada perangkat mobile.
\end{abstract}

Kata kunci: game, tactical role-playing, AndEngine, perangkat mobile, Android Gingerbread, conditional framerate 


\section{PENDAHULUAN}

Perkembangan teknologi mobile baik dari sisi hardware ataupun software mengalami peningkatan yang cukup pesat di dunia. Hal ini memacu banyak pengembang untuk membuat aplikasi yang menarik pada perangkat mobile (Gartner, (2011). Berbagai aplikasi termasuk game dapat dimainkan dengan mudah pada perangkat mobile walaupun memerlukan spesifikasi yang tinggi. Di samping itu, kemampuan multi-touchscreen pada perangkat mobile telah menjadi pendukung yang kuat dalam perkembangan dunia game. Kekhasan suatu game dibedakan berdasarkan genre-nya. Salah satu contoh genre adalah Tactical Role-Playing Game (TRPG) yang menggabungkan elemen RPG tradisional dan strategi. Genre RPG memungkinkan pemain mengontrol sebuah party dan melakukan suatu pertarungan. Genre ini memasukkan gameplay strategi untuk pola pergerakan tactical pada sebuah isometric atau orthogonal grid. Tidak seperti genre lain, TRPG biasanya tidak memberikan fitur multiplayer.

Jarang ditemui TRPG yang menampilkan atau memasukkan elemen kebudayaan Indonesia. Hal ini dikarenakan pengembang TRPG pada umumnya adalah dari luar Indonesia. Masalah umum lainnya adalah keterbatasan daya baterai pada perangkat mobile sehingga membuat pengguna tidak dapat melakukan permainan untuk jangka waktu yang cukup lama. Penelitian ini bertujuan untuk memperkenalkan elemen kebudayaan Indonesia melalui aplikasi game yang diimplementasikan pada perangkat mobile bersistem-operasi Android Gingerbread, menerapkan kecerdasan buatan untuk memaksimalkan permainan, memperkenalkan teknologi AndEngine dalam menampilkan perspektif 2 dimensi, serta mekanisme conditional framerate dalam menekan penggunaan daya baterai agar lebih hemat (Yulianto, 2011). Penelitian ini bermanfaat untuk mendorong minat pengembang dalam negeri untuk membuat lebih banyak aplikasi game sejenis yang mencampurkan elemen kebudayaan Indonesia.

\section{METODE}

Penelitian ini menerapkan metodologi Rational Unified Process (RUP) (Ambler, 2005), meliputi tahap analisis, perancangan, pengembangan, dan perawatan. Tahapan analisis mencakup studi literatur, analisis kebutuhan pengguna, dan analisis game sejenis. Studi literatur meliputi pengkajian buku, artikel, dan jurnal yang berkaitan dengan konsep pengembangan penelitian seperti game design, game battle system, character modelling, dan teknologi mobile. Analisis kebutuhan pengguna melalui media kuesioner dan analisis game sejenis dilakukan dengan me-review keunggulan dan kelemahan game tersebut. Tahapan perancangan dilakukan melalui story, gameplay, character, artificial intelligence, game interface, dan fitur-fitur dalam game. Di dalamnya mencakup perancangan animation sprite dan character model yang menggunakan Adobe Photoshop dan Adobe Flash, dan perancangan game interface menggunakan mekanisme storyboard. Tahapan penulisan (code) menggunakan teknologi Android SDK dan piranti lunak Eclipse sebagai editor dan compiler. Pada tahapan akhir meliputi uji coba dan maintenance dari hasil penelitian yang telah dibuat.

\section{HASIL DAN PEMBAHASAN}

Analisis terhadap data-data diperlukan untuk mendukung penelitian dengan menggunakan metode analisis pengguna dan analisis game sejenis. Analisis pengguna dilakukan dengan penyebaran kuesioner terkait penelitian melalui responden yang pernah memainkan game pada platform Android untuk menjaga validitas data. 


\section{Kuesioner Kebutuhan Pengguna}

1. Apakah Anda pernah memainkan game ber-genre TRPG?

a. Ya

b. $\quad$ Tidak (lanjut ke pertanyaan nomor 6)

2. Judul-judul game TRPG apa saja yang pernah Anda mainkan pada smartphone Anda? (jawaban bisa lebih dari satu)

a. $\quad$ Spectral Souls : Ressurection of the Ethereal Empires

b. Royal Knight : Project Angel the Ressurection of Atlantis

c. Battle for Wesnoth

d. Dungeon Defenders : Second Wave

e. Dungeon Wonders

f. Guns'n'Glory WW2

g. Battleheart

h. Cyber Knight RPG Elite

i. $\quad$ Majesty : Fantasy Kingdom

j. Lainnya: ...

3. Dalam game ber-genre Tactical RPG, berapa banyak pasukan yang Anda inginkan di dalam party Anda?
a. $\quad 1-3$ karakter
b. $\quad 4-6$ karakter
c. $>6$ karakter

4. $\quad J o b$ apa saja yang Anda harapkan ada pada sebuah game TRPG? (jawaban bisa lebih dari satu)
a. Barbarian (serangan fisik tinggi) dengan senjata greatsword, axe, dual-axe

b. $\quad$ Paladin (pertahanan tinggi) dengan senjata sword and shield, dual-shield

c. Assasin (lincah dan persentasi kritikal tinggi) dengan senjata dagger, dual-dagger,

katar

d. Archer (jarak yang jauh) dengan senjata bow, crossbow

e. $\quad$ Priest (healer dan buffer) dengan senjata holy book, holy mace

f. Wizard (serangan magic tinggi) dengan senjata staff, magic wand

g. Lainnya: ...

5. Apakah Anda menginginkan job pada game TRPG berasal dari job dasar dan kemudian dapat berubah menjadi job lanjutan?
a. Ya
b. Tidak

6. Elemen cerita apakah yang membuat Anda tertarik memainkan game TRPG?
a. Percintaan
b. Persahabatan
c. Humor
d. Nilai-nilai kehidupan
e. Lainnya :...

7. Dalam sebuah game TRPG berapa lama waktu yang Anda inginkan untuk menyelesaikan sebuah stage?
a. $\quad<20$ menit
b. $\quad 20$ hingga $<40$ menit
c. $\quad 40$ hingga $<60$ menit
d. $\quad 60$ menit atau lebih 
8. Seberapa lama waktu yang Anda inginkan untuk menyelesaikan sebuah sekuel game pada smartphone?
a. $\quad<3$ jam
b. $\quad 3$ hingga $<6$ jam
c. $\quad 6$ hingga $<9$ jam
d. 9 jam atau lebih

9. Dari mana biasanya Anda mengetahui/mendapatkan informasi mengenai game yang Anda mainkan? (jawaban bisa lebih dari satu)
a. Teman
b. $\quad$ Application market (Android Market, dll.)
c. Website game
d. Media cetak
e. Jejaring sosial/forum

10. Kendala yang dialami ketika bermain pada smartphone Anda?
a. Baterai yang cepat habis
b. Kontrol yang kurang nyaman
c. Dukungan hardware yang tidak sesuai
d. Lainnya :...

11. Berapakah biaya yang dapat Anda keluarkan untuk membeli sebuah game?
a. Gratis (dengan iklan)
b. $\quad<1$ USD
c. $\quad$ Antara 1 USD dan 3 USD
d. Antara 3 USD dan 5 USD
e. $\quad>5$ USD

12. Jika terdapat game TRPG pada smartphone Android dengan ketentuan yang Anda harapkan, apakah Anda bersedia membelinya sesuai dengan harga pada nomor 11?
a. Ya
b. Tidak

13. Apabila Anda telah menyelesaikan versi awal dari sebuah game, apakah Anda tertarik untuk memainkan sekuel berikutnya?
a. $\quad$ Ya
b. Tidak

14. Apakah Anda akan merekomendasikan game TRPG tersebut pada teman anda?
a. Ya
b. Tidak

15. Apa yang menyebabkan Anda berhenti atau beralih ke game lainnya?
a. Sudah tamat
b. Permainan membosankan
c. Terlalu sulit
d. Lainnya: ...

Kuesioner berisi 15 pertanyaan diberikan kepada 64 responden dengan ringkasan hasil sbb: 
Dari 64 responden, terdapat 45 responden (70\%) yang pernah memainkan game ber-genre TRPG, dan 19 responden yang tidak. Hal ini menunjukkan bahwa game ber-genre TRPG termasuk popular.

Game "Spectral Souls: Resurrection of the Ethereal Empires" dan "Battleheart" merupakan game TRPG yang paling banyak dimainkan oleh responden sehingga menjadi acuan dalam melakukan analisis game sejenis pada penelitian ini.

Mayoritas responden (69\%) menginginkan jumlah karakter 4 sampai 6 untuk sebuah party pada game TRPG. Dari hasil tersebut, penelitian ini akan mengembangkan game dengan jumlah anggota party antara 4 hingga 6 karakter.

Assasin, archer, dan wizard merupakan job yang paling diminati pada game TRPG sehingga job tesebut akan menjadi acuan penelitian ini untuk pembuatan game.

69\% responden berminat atas fitur job lanjutan sehingga penelitian ini akan menambahkan fitur tersebut pada perancangan game.

Elemen cerita tentang nilai-nilai kehidupan merupakan elemen yang paling diminati oleh responden (47\%). Karena itu, penelitian ini melakukan implementasi elemen-elemen mengenai nilainilai kehidupan, seperti kesadaran pengelolaan alam, moralitas kebaikan, dan manipulasi media pada perancangan game story.

47\% responden meminati sebuah misi untuk dapat diselesaikan dalam waktu 20 hingga 40 menit, dan 45\% responden menginginkan misi dapat diselesaikan dalam waktu kurang dari 20 menit. Dari hasil persentase mayoritas tersebut, durasi misi pada game akan dirancang beragam di bawah 20 menit dan di antara 20 hingga 40 menit.

36\% responden mengharapkan dapat menyelesaikan sebuah sekuel game dalam jangka waktu enam hingga sembilan jam dan 33\% responden mengharapkan tiga hingga enam jam. Dari hasil persentase mayoritas tersebut, penelitian ini akan merancang titik tengah jangka waktu penyelesaian sekuel game, yaitu antara lima hingga tujuh jam.

Mayoritas responden mendapatkan informasi suatu game melalui media teman dan application market. Hal ini akan menjadi saran bagi peneliti apabila game yang dirancang ingin dipublikasikan.

Kendala utama responden dalam bermain game adalah baterai yang cepat habis (51\%) dan kontrol yang kurang nyaman (36\%). Dari hasil tersebut, beberapa teknik penghematan baterai akan diaplikasikan pada game ini, seperti pengurangan frame rate dan brightness ketika game dimainkan dan penggunaan prinsip 8 aturan emas dalam perancangan layar.

Mayoritas responden lebih memilih game yang gratis walaupun terdapat iklan. Dari hasil tersebut, penelitian awal akan ditujukan pada non-profit. Untuk saran penelitian berikutnya, game dapat dikembangkan lebih lanjut untuk dipasarkan pada kisaran harga kurang dari 1 USD. 97\% responden yang telah menyelesaikan versi awal dari sebuah game tertarik untuk memainkan sekuel berikutnya. Hal ini menjadi saran bagi penelitian berikutnya untuk membuat sekuel lanjutan dari game ini.

Mayoritas responden (97\%) akan merekomendasikan game TRPG kepada rekan-rekannya. Hal ini menunjukkan bahwa penyebaran game tidak hanya melalui media application market, namun juga melalui mouth-to-mouth. 
Sebagian besar responden (52\%) mengatakan bahwa permainan yang membosankan adalah alasan utama mereka untuk beralih ke game yang lain. Untuk itu, perancangan game akan memasukkan beberapa fitur-fitur menarik, seperti recruitable soldier, recruitable hero dan dungeon bertingkat agar meminimalkan rasa bosan permainan.

\section{Analisis Game Sejenis}

Analisis game sejenis dilakukan pada game ber-genre TRPG yang paling banyak dimainkan oleh responden, yaitu "Spectral Souls: Ressurection of the Ethereal Empires" dan "Battleheart". Analisis ini membandingkan beberapa komponen umum pada game tersebut (Tabel 1).

Tabel 1

Perbandingan Game Sejenis

\begin{tabular}{|c|c|c|c|}
\hline Komponen & Spectral Souls & Battleheart & $\begin{array}{l}\text { Protector of Acacia } \\
\text { (Penelitian) }\end{array}$ \\
\hline Giliran & Turn-based & Real-time & Turn-based \\
\hline Jumlah anggota party & 5 karakter & 4 karakter & 5 karakter \\
\hline Grafik dan animasi & $2.5 \mathrm{D}$ & $2 \mathrm{D}$ & $2 \mathrm{D}$ \\
\hline Alur cerita & Multiple & Linear & Linear \\
\hline Elemen cerita & $\begin{array}{l}\text { Kepemimpinan, } \\
\text { peperangan antar- } \\
\text { kekuatan }\end{array}$ & $\begin{array}{l}\text { Mengalahkan musuh- } \\
\text { musuh yang meresahkan }\end{array}$ & $\begin{array}{l}\text { Nilai-nilai kehidupan, } \\
\text { peperangan antar- } \\
\text { kerajaan }\end{array}$ \\
\hline Durasi stage & 20-40 menit & 10-30 menit & 20-40 menit \\
\hline Durasi permainan & 75 jam & 8 jam & 5-7 jam \\
\hline Harga rilis & 15 USD & 2.99 USD & Gratis dan 0.99 USD \\
\hline Faktor menarik & $\begin{array}{l}\text { Grafik 2.5D dan } \\
\text { durasi permainan } \\
\text { yang panjang }\end{array}$ & $\begin{array}{l}\text { Grafik unik dan } \\
\text { banyaknya pilihan job }\end{array}$ & $\begin{array}{l}\text { Penggunaan elemen- } \\
\text { elemen Indonesia dan } \\
\text { sistem kontrol yang } \\
\text { menarik. }\end{array}$ \\
\hline
\end{tabular}

\section{Perancangan UML}

Perancangan sistem yang digunakan untuk merancang sistem pada game adalah perancangan UML yang meliputi Class Diagram (Gambar 1), Use Case Diagram (Gambar 2), Sequence Diagram (Gambar 3) dan Activity Diagram (Gambar 4). 


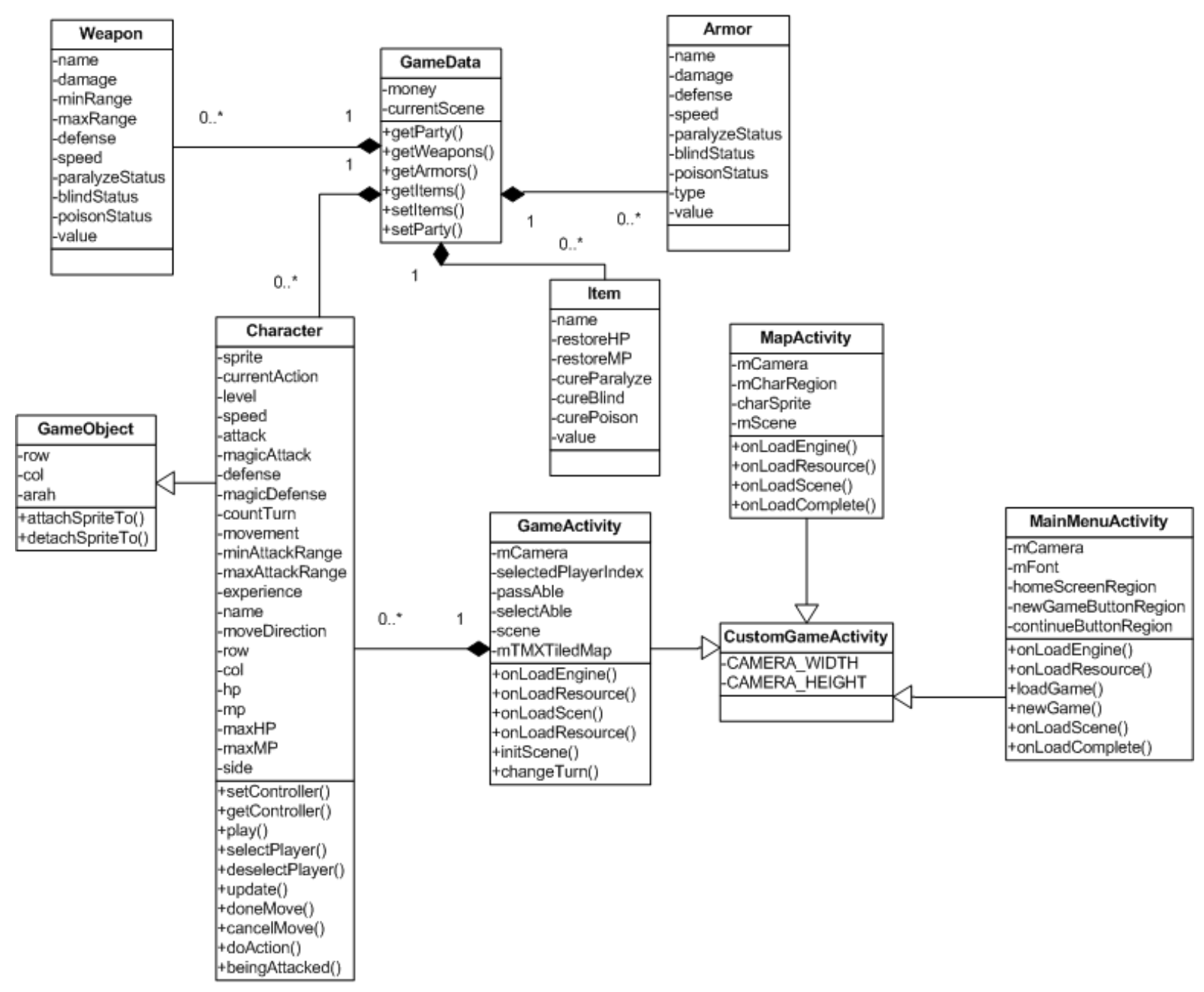

Gambar 1. Class diagram.

Class Diagram digunakan untuk menggambarkan struktur pemodelan dari sistem yang dibangun. Setiap class mewakili setiap entity pada sistem dan terdiri dari properti serta perilaku dari class tersebut. Sebagai contoh, Class Character memiliki atribut name yang merupakan nama karakter, atribut movement yang mengatur pergerakan, dan perilaku play agar dapat melakukan permainan. Class GameData memiliki atribut money yang berfungsi untuk menyimpan data keuangan dan perilaku getWeapon untuk membeli senjata.

Use Case Diagram digunakan untuk menjabarkan tahap-tahap yang dilalui oleh aktor dalam melakukan setiap kegiatan yang berhubungan dengan sistem. Pada Use Case Diagram di atas terdapat dua aktor, yaitu admin dan pemain. Aktor admin dapat menambah, mengubah, dan menghapus game content. Aktor pemain dapat memulai, menyimpan, dan melanjutkan permainan, melihat world-map, melakukan transaksi, merekrut dan melihat status karakter, mengatur equip, serta melakukan pertempuran.

Sequence Diagram digunakan untuk menjabarkan aliran proses pertukaran pesan antara pelaku dengan sistem atau satu class ke class lainnya, sedangkan Activity Diagram digunakan untuk menjabarkan daur hidup suatu class pada sistem. Sequence Diagram dan Activity Diagram di atas menggambarkan aliran proses ketika pemain memulai permainan game melibatkan class Pemain, class 
UINewGame, dan Class XML. Daur hidup class akan berhenti setelah tampilan window dialog awal muncul.

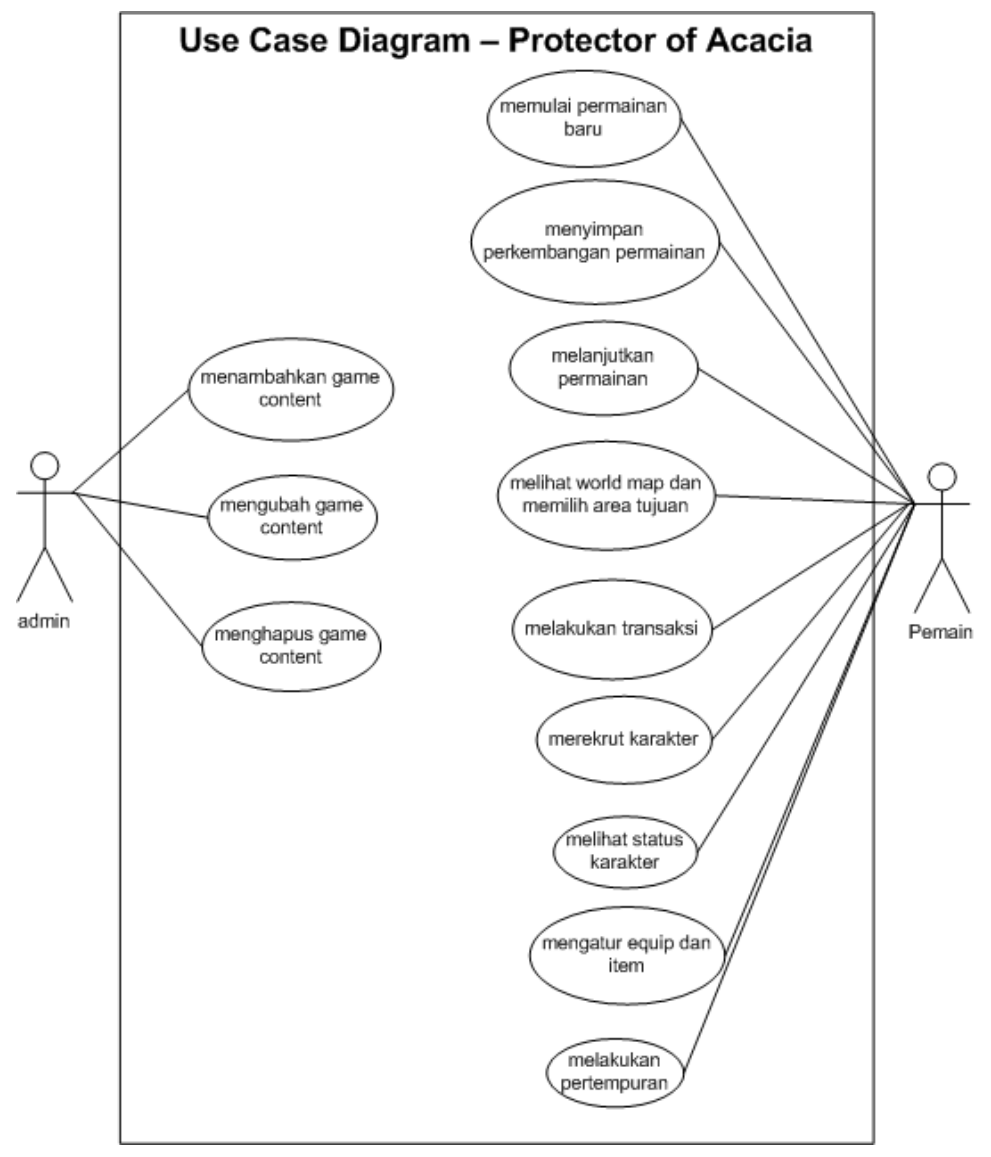

Gambar 2. Use case diagram.

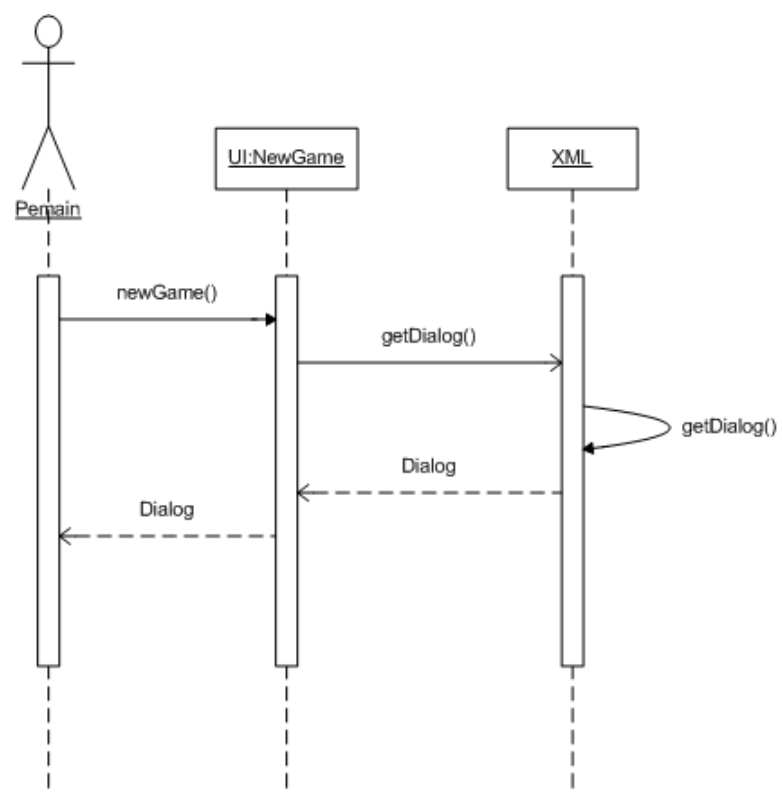

Gambar 3. Sequence diagram. 


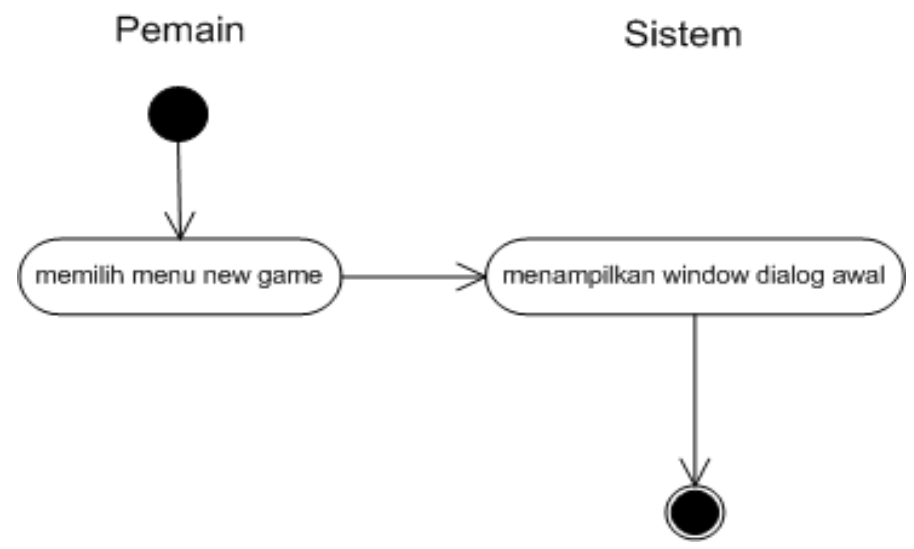

Gambar 4. Activity diagram.

\section{Pengembangan dan Implementasi Piranti Lunak}

Pada tahap pengembangan, teknologi AndEngine digunakan sebagai framework utama dan kecerdasan buatan diimplementasikan pada pergerakan aktor musuh. AndEngine adalah sebuah 2D OpenGL Game Engine untuk platform Android yang diciptakan oleh Nicolas Gramlich pada pertengahan 2010. AndEngine digunakan untuk memenuhi kebutuhan game development framework yang gratis dan mudah digunakan. Lebih dari 2000 game yang menggunakan framework AndEngine telah dipasarkan, dan code dari AndEngine telah dieksekusi lebih dari satu juta kali.

Fitur-fitur AndEngine meliputi Android-Optimized dan Android 1.6 Compatibility sebagai framework yang bekerja pada platform Android versi 1.6 (Donut), SplitiScreen untuk mendukung fasilitas pembagi layar pada perangkat Android, Network Multiplayer untuk mendukung fasilitas bermain multiplayer, Live-Wallpapers untuk mendukung pembuatan wallpaper hidup yang bergerak, MultiTouch untuk mendukung penggunaan teknologi multitouch pada perangkat yang mendukung, dan Physics-Engine (Box2D) untuk mendukung perhitungan fisika dalam pembuatan aplikasi menggunakan teknologi Box2D.

Berikut ini beberapa contoh tampilan layar yang dibuat untuk aplikasi game ini (Gambar 5 8), serta tampilan Game Content Editor (Gambar 9).

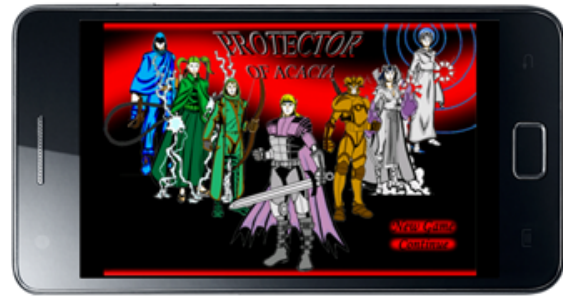

Gambar 5. Tampilan awal.

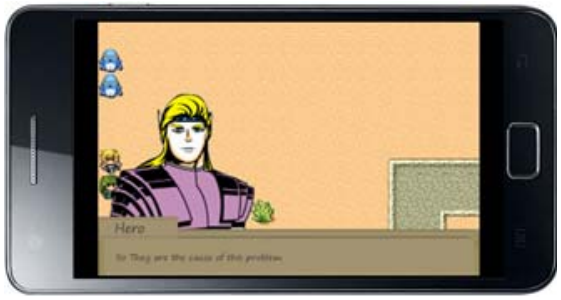

Gambar 6. Tampilan Dialog. 


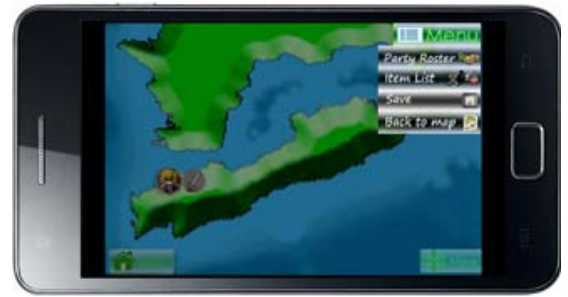

Gambar 7. Tampilan World Map.

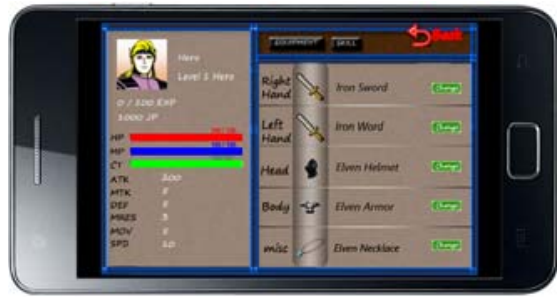

Gambar 8. Tampilan Character Detail.

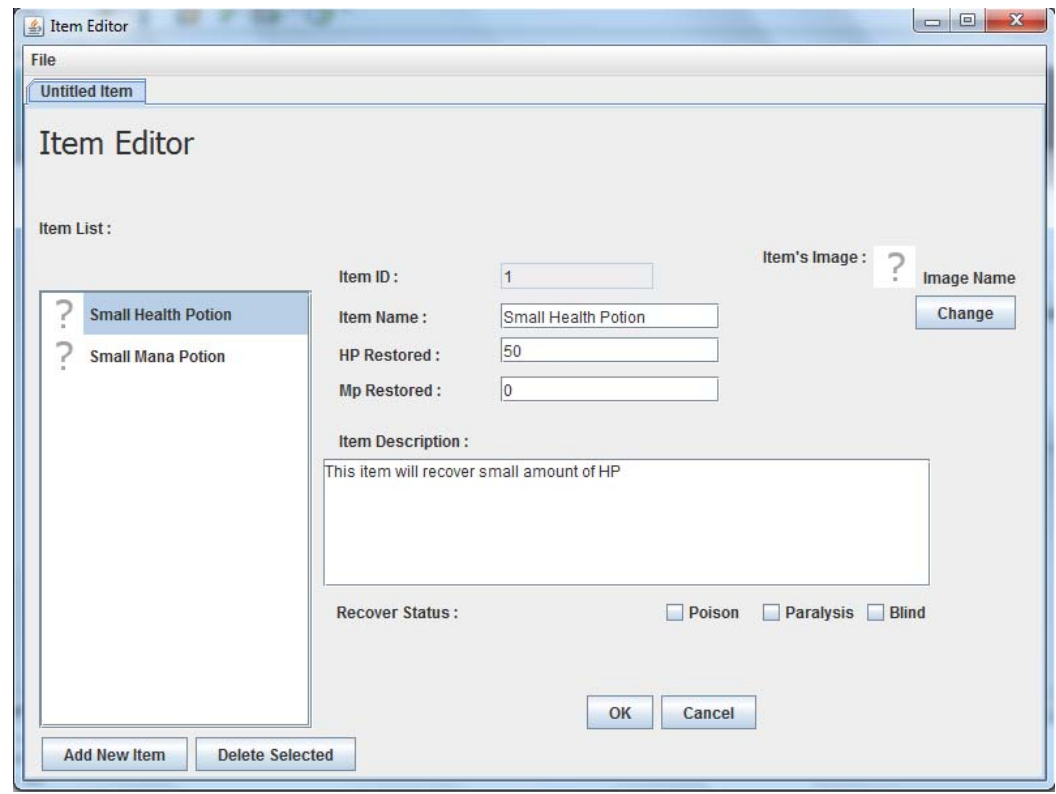

Gambar 9. Tampilan Game Content Editor (game engine).

\section{Evaluasi}

Evaluasi terhadap aplikasi dilakukan pada 8 aturan emas Interaksi Manusia dan Komputer (Shneiderman et al., 2010), 5 elemen multimedia (Vaughan, 2006), kuesioner yang ditujukan pada pengguna game dengan mencoba terlebih dahulu game; dan daya tahan baterai. Pada aplikasi diterapkan framerate yang berbeda saat pemain berada di area pertarungan, penjelajahan, dan melakukan transaksi guna menekan penggunaan daya baterai.

Pengkajian terhadap 8 aturan emas mencakup penerapan konsistensi pada penyeragaman tampilan GUI dan font, memungkinkan pengguna menggunakan shortcut pada halaman status dan penggunaan skill/item, adanya umpan balik yang informatif pada saat penampilan informasi barang, penggunaan dialog box atau message box pada area pertempuran, pencegahan kesalahan agar pengguna mendapatkan konfirmasi ulang ketika membeli atau menjual suatu barang, memungkinkan pembalikan aksi yang mudah melalui fitur save dan load, mendukung kendali internal melalui peran pengguna sebagai aktor dalam aplikasi, dan mengurangi beban ingatan jangka pendek pengguna dengan perancangan yang ringkas dan jelas.

Evaluasi 5 elemen multimedia mencakup teks yang ditampilkan pada informasi item dan equipment, gambar yang ditampilkan pada saat portrait karakter, suara yang diimplementasikan pada background music dan sound effect saat pemain berada di world-map dan battle, animasi yang 
diterapkan pada saat aktor bergerak dalam pertarungan di world-map, dan video yang merupakan bentuk lain dari animasi yang sekuensial.

Evaluasi terhadap aplikasi hasil penelitian dilakukan melalui kuesioner evaluasi yang diberikan pada 30 responden. Hasil dari kuesioner evaluasi tersebut sebagai berikut.

\section{Kuesioner Evaluasi}

1. Berapa waktu yang Anda butuhkan untuk memainkan sebuah stage pada game ini?
a. $\quad<20$ menit
b. $\quad 20$ hingga $<40$ menit
c. $\quad 40$ hingga $<60$ menit
d. $\quad 60$ menit atau lebih

2. Apakah kontrol (penguasaan) untuk memainkan game ini mudah?
a. Ya, mudah
b. Tidak mudah

3. Apakah tampilan (interface) dari game ini menarik?
a. Ya, menarik
b. Tidak menarik

4. Apakah Anda merasakan adanya elemen cerita pada game ini berupa nilai-nilai kehidupan, seperti kebaikan selalu menang dan pemutarbalikan fakta oleh media?
a. $\quad$ Ya
b. Tidak

5. Apabila game ini dijual dengan harga kurang dari US\$1, apakah Anda berniat untuk membelinya?
a. $\quad$ Ya, saya berniat membeli
b. Tidak

6. Apakah game ini membosankan apabila dimainkan lebih dari sekali?
a. $\quad$ Ya
b. Tidak

7. Apabila ada sekuel lanjutan dari game ini, apakah Anda tertarik untuk memainkannya?
a. Ya
b. Tidak

8. Setelah memainkan game ini, apakah Anda tertarik untuk mengembangkan game yang mengandung beberapa elemen Indonesia?
a. $\quad$ Ya
b. Tidak

9. Apakah anda akan merekomendasikan game ini kepada teman Anda?
a. $\quad$ Ya
b. Tidak 
Berikut adalah digram hasil evaluasi berdasarkan kuesioner (Gambar 10 - 18):

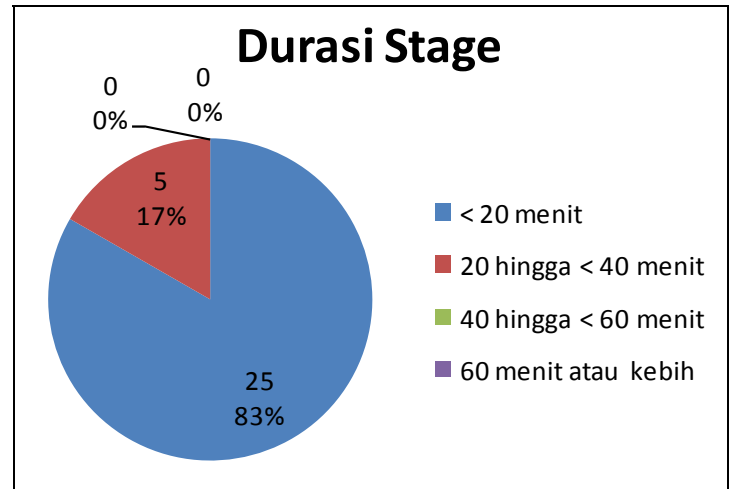

Gambar 10. Evaluasi terhadap durasi Stage.

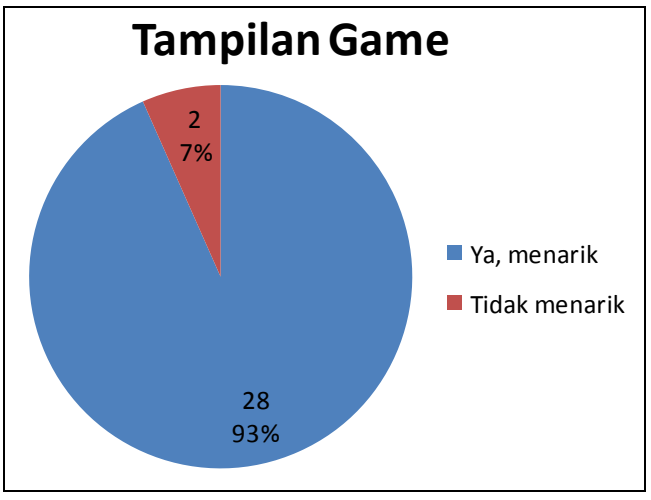

Gambar 12. Evaluasi terhadap tampilan game.

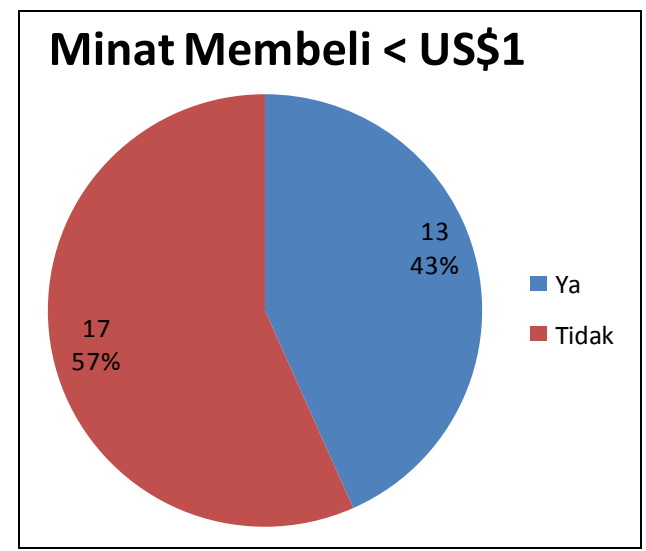

Gambar 14. Evaluasi terhadap minat membeli dengan harga $<$ US\$1.

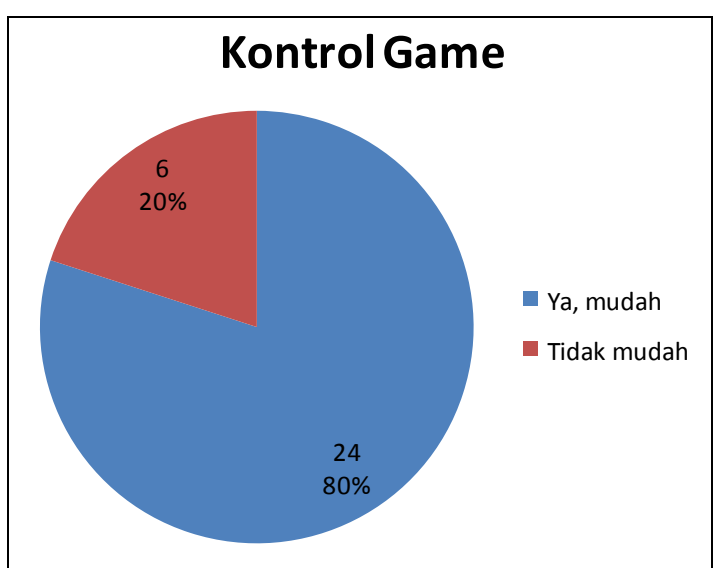

Gambar 11. Evaluasi terhadap kemudahan kontrol game.

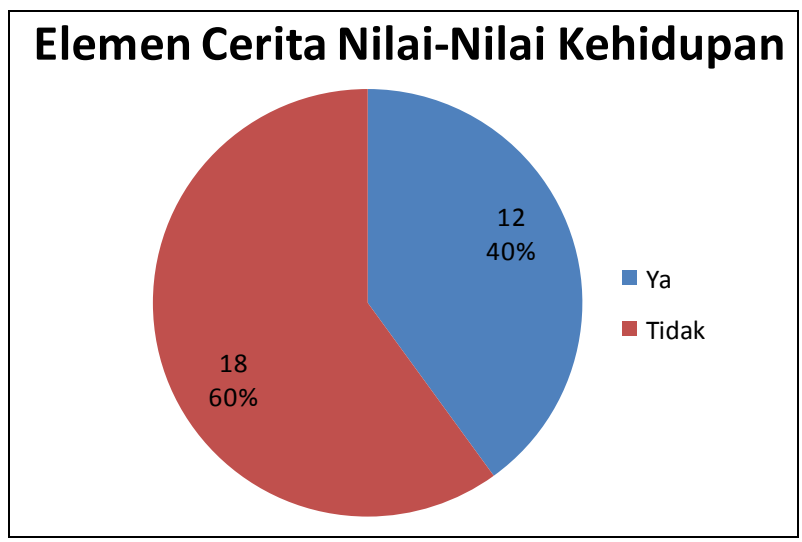

Gambar 13. Evaluasi terhadap adanya elemen cerita nilai-nilai kehidupan.

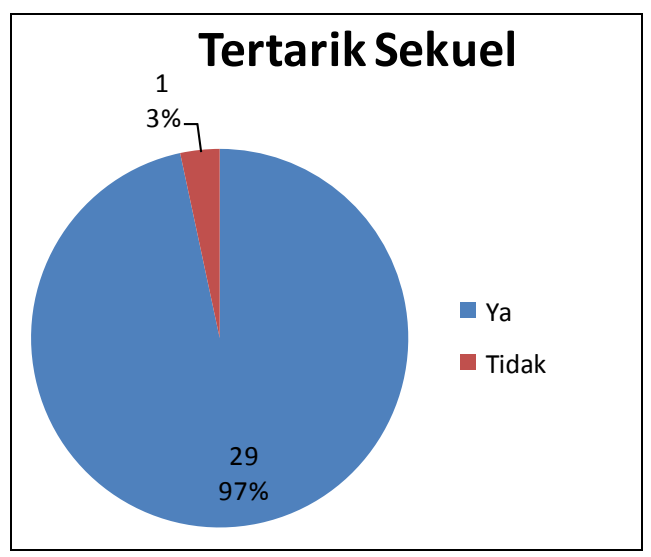

Gambar 16. Evaluasi terhadap ketertarikan sekuel berikutnya. 


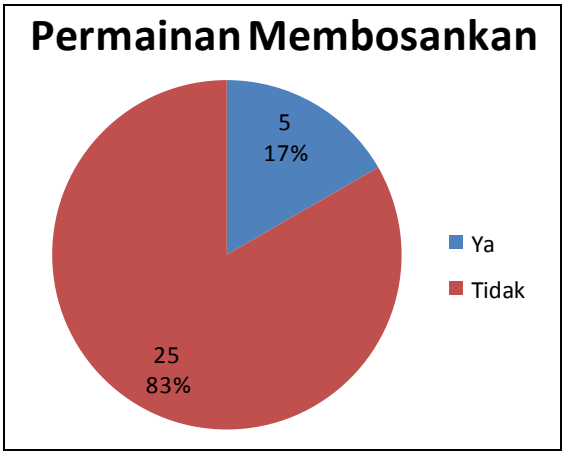

Gambar 15. Evaluasi terhadap tingkat kebosanan permainan.

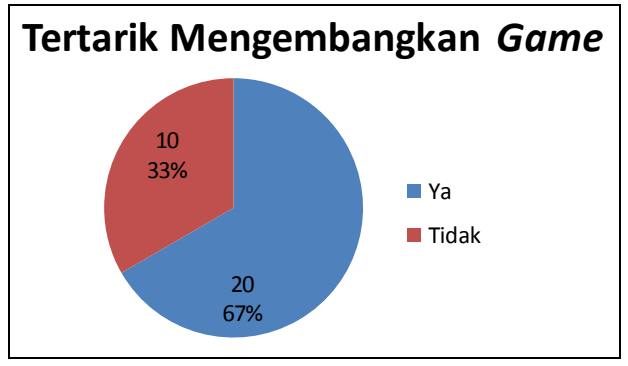

Gambar 17. Evaluasi terhadap ketertarikan mengembangkan game dengan elemen budaya Indonesia

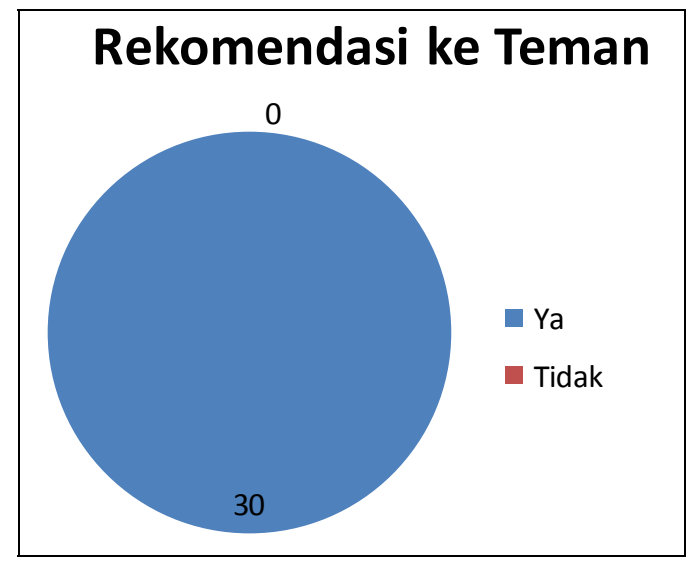

Gambar 18. Evaluasi terhadap rekomendasi game ke rekan lainnya.

Kendala utama saat bermain game pada smartphone adalah baterai yang cepat habis. Oleh sebab itu, penelitian ini menerapkan metode conditional framerate untuk mengurangi penggunaan daya baterai pada saat memainkan game ini. Beberapa penerapan tingkat framerate bergantung pada prioritas kebutuhan animasi. Pada saat pertarungan, framerate yang digunakan adalah $30 \mathrm{fps}$. Ketika melakukan penjelajahan world map, penggunaan framerate diturunkan menjadi 20 fps. Pada saat melakukan transaksi, tingkat framerate yang digunakan hanya 10 fps. Berikut ini adalah tabel hasil uji coba perbandingan penggunaan daya baterai selama 30 menit (Tabel 2).

Tabel 2

Evaluasi Persentase Penggunaan Baterai Selama 30 Menit

\begin{tabular}{ccc}
\hline Uji Coba & Fix Framerate (30 fps) & Conditional Framerate \\
\hline 1 & $15 \%$ & $15 \%$ \\
\hline 2 & $15 \%$ & $10 \%$ \\
\hline 3 & $10 \%$ & $5 \%$ \\
\hline Rata-rata & $\mathbf{1 3 . 3 3 \%}$ & $\mathbf{1 0} \%$ \\
\hline
\end{tabular}

Pengujian dilakukan menggunakan perangkat mobile Samsung Galaxy SII dan Sony Ericsson Xperia X10. Dari Tabel 2 di atas dapat disimpulkan bahwa secara rata-rata terjadi penghematan daya 
baterai sekitar $\frac{(13.33 \%-10 \%)}{13.33 \%}=25 \%$ dengan metode conditional framerate per 30 menit
penggunaan.

\section{PENUTUP}

Simpulan yang diperoleh dari penelitian ini yaitu aplikasi yang dikembangkan dengan teknologi AndEngine dapat memenuhi durasi, kontrol penggunaan, tampilan grafik yang sesuai dengan kebutuhan pengguna; Implementasi kecerdasan buatan pada otomatisasi pergerakan aktor membuat game terasa tidak membosankan; dan Dukungan teknik conditional framerate dapat menghemat baterai device sebesar 25\% dalam 30 menit.

Saran untuk penelitian dan pengembangan lebih lanjut yaitu alur cerita harus diimplementasikan pada awal permainan agar pengguna sudah dapat merasakan elemen cerita game; Pembuatan sekuel berikutnya; Penyebaran informasi game juga melalui media website (internet); Pembuatan game versi lite (tak berbayar) dan full (berbayar); dan Penetapan harga jual game (apabila game berbayar dan ingin dipasarkan) adalah berkisar dibawah US\$ 1.

\section{DAFTAR PUSTAKA}

Ambler, Scott W. (2005). A Manager's Introduction to the Rational Unified Process (RUP). Ambysoft. Diakses $\quad 5 \quad$ November 2011 dari http://www.ambysoft.com/downloads/managersIntroToRUP.pdf.

Gartner. (2011). Gartner says sales of mobile devices in second quarter of 2011 grew 16.5 percent year-on-year; smartphone sales grew 74 percent. Gatner Newsroom. Diakses 30 Oktober 2011 dari http://www.gartner.com/it/page.jsp?id=1764714.

Shneiderman, B., Plaisant, C., Cohen, M., Jacobs, S. (2010). Designing the User Interface, Strategy for Effective Human-Computer Interaction (fifth edition). Boston: Addison-Wesley.

Vaughan, Tay. (2006). Multimedia: Making It Work (edisi 6). Yogyakarta: Penerbit Andi.

Yulianto, Budi. (2011). Penerapan action RPG pada perangkat mobile berbasiskan iOS. Jurnal ComTech, 2(2). 